\title{
Hubungan Pengetahuan dan Sikap dengan Perilaku Merokok pada Remaja di SMA PGRI 2 Palembang Tahun 2017
}

\author{
Erike Septa Prautami ${ }^{1 *}$, Sri Rahayu ${ }^{2}$ \\ 1*. Akbid Pondok Pesantren Assanadiyah Palembang, Jl. Banten VI, Kota Palembang, Indonesia, 30117 \\ 2. Akbid Pondok Pesantren Assanadiyah Palembang, Jl. Banten VI, Kota Palembang, Indonesia, 30117 \\ *e-mail: erikeseptaprautami@gmail.com
}

\begin{abstract}
Smoking can harm the health of the body because it could cause diseases such as cardiovascular and cancer, lung cancer, the esophagus and larynx, and the cavity of the mouth caused by components and dangerous substances in cigarettes such as carbon dioxide and tar and nicotine research objectives to know the relationship knowledge and attitudes with the behavior smoking. Research methodology the used in this research was survey analytic with the approach "Cross Sectional" Performed in high school PGRI 2 Palembang on 5 - 8 January 2017 with respondents as many as 120 people. The data raised using quesionare bivariat and analysis done by test chi-square. Saying the results of this research shows there is a knowledge and attitudes with the behavior of smoking with $p$ value $=0,000$. To the students suggested to reduce smoking habit that could jeopardize health.
\end{abstract}

Keywords: Attitude, cigarette behavior, knowledge

\begin{abstract}
Abstrak
Merokok dapat mengganggu kesehatan tubuh karena dapat menimbulkan penyakit seperti penyakit jantung dan kanker, baik kanker paru-paru, esofagus, laring, dan rongga mulut hal ini disebabkan oleh komponen dan zat-zat yang berbahaya dalam rokok seperti karbon monoksida, tar dan nikotin. Di provinsi Sumatera Selatan, tahun 2013 ada 50\% anak sekolah yang sudah pernah merokok dan dilaporkan bahwa jumlah anak laki-laki adalah $46 \%$ lebih tinggi dibandingkan anak perempuan $4 \%$. Tujuan penelitian untuk mengetahui hubungan pengetahuan dan sikap dengan perilaku merokok. Metode penelitian yang digunakan dalam penelitian ini adalah Survey Analitik dengan pendekatan "Cross Sectional" yang dilakukan pada siswa dan siswi di SMA PGRI 2 Palembang pada tanggal 5 - 8 Januari 2017 dengan responden sebanyak 120 orang. Data di kumpulkan menggunakan kuesioner dan analisa bivariat yang dilakukan dengan uji chi-square. Hasil penelitian ini menunjukkan ada hubungan pengetahuan dan sikap dengan perilaku merokok dengan $\mathrm{p}$ value $=0,000$. Kepada para siswa disarankan agar mengurangi kebiasaan merokok yang dapat membahayakan kesehatan.
\end{abstract}

Kata kunci: Pengetahuan, perilaku merokok, sikap 


\section{Pendahuluan}

Perilaku menyimpang adalah semua tindakan yang menyimpang dari norma-norma yang berlaku dalam suatu sistem sosial dan menimbulkan usaha dari pihak yang berwenang untuk memperbaiki perilaku menyimpang tersebut. Perilaku menyimpang juga sering disebut sebagai suatu penyakit dalam masyarakat atau penyakit sosial. Penyakit sosial tersebut dapat diartikan sebagai segala tingkah laku yang dianggap tidak sesuai, melanggar norma-norma umum, adat-istiadat, hukum formal, atau tidak bisa diintegrasikan dalam pola tingkah laku umum (Nurseno, 2009).

Perilaku menyimpang remaja merupakan masalah yang sedang dicari jalan keluarnya. Banyak faktor yang menjadi penyebab perilaku menyimpang remaja. Penelitian Astuti (2004) menjelaskan bahwa proses pengasuhan anak sangat mempengaruhi perkembangan remaja. Pola asuh yang tidak sesuai dengan perkembangan zaman yang terus berubah akan menyebabkan remaja tersebut melakukan hal-hal yang menyimpang. Demikian juga dengan penelitian Rozy (2010) menambahkan faktor-faktor penyebab perilaku menyimpang remaja yakni, faktor lingkungan keluarga, lingkungan sekolah, lingkungan masyarakat, televisi sebagai salah satu media yang dapat menyebabkan perilaku menyimpang, dan lingkungan pergaulan atau pertemanan baik di sekolah ataupun di luar sekolah menjadi salah satu faktor penunjang terjadinya perilaku menyimpang remaja.

Merokok adalah membakar tembakau kemudian dihisap, baik menggunakan rokok maupun menggunakan pipa. Temparatur sebatang rokok yang tengah dibakar adalah 900C untuk ujung rokok yang dibakar, dan 300C untuk ujung rokok yang terselip di antara bibir perokok. Kondisi teman sebaya yang kurang baik membuat perlaku seseorang mengikuti hal-hal yang tidak baik seperti merokok (Aula, 2010).

Rokok memiliki 4000 zat kimia berbahaya untuk kesehatan, diantaranya adalah nikotin yang bersifat adiktif dan tar yang bersifat karsinogenik. Rokok memang hanya memiliki 8-20 mg nikotin, yang setelah dibakar 25 persennya akan masuk kedalam darah. Namun, jumlah kecil ini hanya membutuhkan waktu 15 detik untuk sampai ke otak. Dengan merokok mengurangi jumlah sel-sel berfilia (rambut getar), menambah sel lendir sehingga menghambat oksigen ke paru-paru sampai resiko delapan kali lebih besar terkena kanker dibandingkan mereka yang hidup sehat tanpa rokok (Mu'tadin, 2002).

Merokok juga dapat mengganggu kesehatan tubuh karena dapat menimbulkan penyakit seperti kardiovaskuler dan kanker, baik kanker paru-paru, esofagus, laring, dan rongga mulut yang disebabkan oleh komponen dan zat-zat yang berbahaya dalam rokok seperti karbon monoksida, tar dan nikotin (Depkes, 2004).

Menurut data dari WHO (World Health Organization) pada tahun 2013 ada 10 negara dengan perokok tertinggi yaitu: China 390 juta perokok atau 29\% penduduk, India 144 juta perokok atau 12.5\% penduduk, Indonesia 65 juta perokok atau $28 \%$ penduduk, Rusia 61 juta perokok atau $43 \%$ penduduk, Amerika Serikat 58 juta perokok atau $19 \%$ penduduk, Jepang 49 juta perokok atau 38\% penduduk, Brazil 24 juta perokok atau $12.5 \%$ penduduk, Bangladesh 23.3 juta perokok atau 23.5\% penduduk, Jerman 22.3 juta perokok atau $27 \%$, Turki 21.5 juta perokok atau $30.5 \%$.

Data statistik perokok di Indonesia pada tahun 2013 dari kalangan anak-anak dan remaja yaitu: Pria 24.1\% anak/remaja pria, wanita $4.0 \%$ anak/remaja wanita atau $13.5 \%$ anak/remaja Indonesia. Sedangkan perokok dikalangan dewasa pria $63 \%$ pria dewasa, wanita $4.5 \%$ wanita dewasa, atau $34 \%$ perokok dewasa. Jika digabungkan antara perokok kalangan anak, remaja, dewasa, maka jumlah perokok Indonesia sekitar 27.6\%. Artinya setiap 4 orang Indonesia, terdapat seorang perokok (BPS, 2013). Di provinsi Sumatera Selatan, tahun 2013 ada 50\% anak sekolah yang sudah pernah merokok dan dilaporkan bahwa jumlah anak laki-laki adalah $46 \%$ lebih tinggi dibandingkan anak perempuan $4 \%$ (BPS, 2013).

Adapun prevalensi remaja pria perokok aktif usia 13-15 tahun adalah 24,5\%, dan remaja usia 15-19 tahun prevalensinya 33\%. Lebih memprihatinkan, menurut Hasil penelitian membuktikan kebiasaan merokok meningkatkan risiko timbulnya berbagai penyakit seperti penyakit jantung dan gangguan pembuluh darah, kanker paru-paru, kanker rongga mulut, kanker laring, kanker esofagus, bronkhitis, tekanan darah tinggi, impotensi serta gangguan kehamilan dan cacat pada janin (Aula, 2010).

Perilaku adalah semua kegiatan atau aktivitas manusia, baik yang dapat diamati langsung maupun yang tidak dapat diamati langsung oleh pihak luar (Notoadmojo, 2007). Konsep umum yang digunakan untuk mendiagnosis perilaku adalah konsep dari Lawrence Green (1980) (dalam Notoadmodjo, 2007). Menurut Green, perilaku dipengaruhi oleh tiga faktor utama yaitu: faktor predisposisi (predisposing factors) mencakup pengetahuan dan sikap masyarakat terhadap kesehatan, tradisi, dan kepercayaan masyarakat terhadap hal-hal yang berkaitan dengan kesehatan, sistem nilai yang dianut masyarakat, tingkat pendidikan, tingkat sosial ekonomi, dan sebagainya; Faktor-faktor pemungkin (enambling factors) mencakup ketersediaan sarana dan prasarana atau fasilitas kesehatan bagi masyarakat; dan faktor-faktor penguat (reinforcing factors) meliputi faktor sikap dan perilaku tokoh masyarakat,tokoh agama,dan para petugas termasuk petugas kesehatan.

Pengetahuan adalah segala sesuatu yang diketahui atau kepandaian. Pengetahuan merupakan hasil dari tahu. Ini terjadi setelah seseorang melakukan penginderaan terhadap suatu objek tertentu, yakni indera penglihatan, pendengaran, penciuman, rasa dan raba. Sebagian besar pengetahuan manusia diperoleh melalui mata dan telinga. Pengetahuan / kognitif merupakan domain yang sangat penting dalam membentuk tindakan seseorang (Azwar, 2007). 
Sikap adalah bagaimana pendapat atau penilaian orang atau responden terhadap hal yang terkait dengan kesehatan, sehat-sakit dan faktor yang terkait dengan faktor resiko kesehatan. Newcomb salah seorang ahli psikologi social menyatakan bahwa sikap adalah merupakan kesiapaan atau kesediaan untuk bertindak, dan bukan merupakan pelaksanaan motif tertentu. Dalam kata lain fungsi sikap belum merupakan tindakan (reaksi terbuka) atau aktivitas, akan tetapi merupakan predisposisi perilaku (tindakan), atau reaksi tertutup (Notoatmodjo, 2010).

Salah satu peran perawat adalah sebagai educator, maka dari itu dalam mencegah semakin banyaknya remaja yang merokok perawat dapat melakukan penyuluhan dengan memberikan pendidikan kesehatan pada remaja dan masyarakat pada umumnya (Azwar, 2010).

Dari studi pendahuluan yang dilakukan di SMA PGRI 2 Palembang pada tanggal 3 November 2016 didaptkan hasil dari 20 siswa didapatkan sebanyak 15 siswa merokok. Diantaranya 9 perokok aktif dan 6 orang perokok pasif, selain itu sebagian besar dari mereka memiliki pengetahuan yang kurang tentang bahaya merokok yaitu sebanyak 11 siswa.

Hasil penelitian yang dilakukan Rahmadi (2013) tentang hubungan pengetahuan dan sikap terhadap rokok dengan kebiasaan merokok siswa SMP di kota Padang menujukkan bahwa tidak ada hubungan yang bermakna antara pengetahuan dan sikap dengan kebiasaan merokok pada siswa SMP dengan p value 1. Sementara itu hasil penelitian Purba (2009) tentang hubungan karakteristik, pengetahuan, dan sikap remaja laki - laki terhadap kebiasaan merokok di SMU Parulian 1 Medan tahun 2009 menunjukkan bahwa ada hubungan antara umur dengan perilaku merokok (p value 0,041), dan tidak ada hubungan pengetahuan ( $\mathrm{p}$ value 0,234 ), dan sikap ( $\mathrm{p}$ value 0,657 ) terhadap perilaku merokok pada remaja.

Berdasarkan latar belakang di atas maka peneliti tertarik untuk meneliti tentang hubungan pengetahuan dan sikap dengan perilaku merokok pada remaja di SMA PGRI 2 Palembang tahun 2017.

\section{Metode}

Metode penelitian yang digunakan dalam penelitian ini adalah Survey Analitik dengan pendekatan "Cross Sectional". Penelitian ini dilaksanakan di SMA PGRI 2 Palembang pada tanggal 5 - 8 Januari 2017. Populasi dalam penelitian ini adalah siswa SMA PGRI 2 Palembang. Jumlah sampel dalam penelitian ini adalah 120 responden, dengan tehnik total sampling.

\section{Pengumpulan Data}

1. Data Primer

Data primer yang digunakan dalam penelitian ini diperoleh dari kuesioner yang terdiri dari pertanyaan pembahasan seputar Merokok.

2. Data Sekunder

Data sekunder dalam penelitian ini diperoleh dan dikumpulkan peneliti tentang jumlah perokok di SMA PGRI 2 Palembang.

\section{Pengelolahan Data}

1. Editing

Hasil wawancara angket, atau pengamatan dari lapangan harus dilakukan penyuntingan (editing) terlebih dahulu. Secara umum editing adalah merupakan kegiatan untuk pengecekan dan perbaikan isian formulir atau kuesioner.

2. Coding

Kuesioner semua setelah diedit atau disunting, selanjutnya dilakukan peng "kodean" atau "coding", yakni mengubah data berbentuk kalimat atau huruf menjadi data atau angka bilangan.

3. Data Entry (memasukkan data) atau Processing

Data, yakni jawaban dari setiap responden yang dalam bentuk "kode" (angka atau huruf) dimasukkan ke dalam program atau "software" computer.

4. Pembersihan Data (cleaning)

Data dari setiap sumber atau responden, apabila semua selesai di masukkan, perlu dicek kembali untuk melihat kemungkinan adanya kesalahan kode, ketidaklengkapan, dan sebagainya.

\section{Analisa data}

1. Analisis Univariat

Data yang diperoleh dari hasil pengumpulan dan disajikan dalam bentuk tabel distribusi frekuensi.

2. Analisisis Bivariat

Analisis dilakukan untuk mengetahui interaksi dua variabel, baik berupa komparatif, asosiatif, maupun korelatif. Data diolah dengan SPSS dengan menggunakan uji chi-squre, dengan tingkat kemaknaan $\alpha=0,05$. 


\section{Hasil}

Tabel 1. Distribusi frekuensi responden berdasarkan pengetahuan pada remaja di sma pgri 2 palembang tahun 2017

\begin{tabular}{ccc}
\hline Pengetahuan & Frekuensi & Presentase (\%) \\
\hline Tinggi & 69 & 57,5 \\
Rendah & 51 & 42,5 \\
\hline Total & 120 & 100.0 \\
\hline
\end{tabular}

Berdasarkan tabel 1 diatas menunjukkan bahwa dari 120 responden, 69 resonden (57.5\%) yang memiliki tingkat pengetahuan tinggi dan 51 responden $(42.5 \%)$ yang tingkat pengetahuannya rendah.

Tabel 2. Distribusi frekuensi responden berdasarkan sikap pada remaja di sma pgri 2 palembang tahun 2017

\begin{tabular}{ccc}
\hline Sikap & Frekuensi & Presentase (\%) \\
\hline Positif & 89 & 74,2 \\
Negatif & 31 & 25,8 \\
\hline Total & 120 & 100.0 \\
\hline
\end{tabular}

Berdasarkan tabel 2 diatas menunjukkan sikap 89 responden (74.2\%) yang memiliki sikap postif sedangkan 31 responden $(25.8 \%)$ yang memiliki sikap negatif.

Tabel 3. Distribusi frekuensi responden berdasarkan perilaku merokok pada remaja di sma pgri 2 palembang tahun 2017

\begin{tabular}{ccc}
\hline Perilaku Merokok & Frekuensi & Presentase (\%) \\
\hline Merokok & 76 & 63,3 \\
Tidak Merokok & 44 & 36,7 \\
\hline Total & 120 & 100.0
\end{tabular}

Berdasarkan tabel 3 diatas, perilaku merokok 76 responden (63.3\%) yang merokok sedangkan tidak merokok 44 responden $(36.7 \%)$.

Tabel 4. Hubungan antara pengetahuan dengan perilaku merokok

\begin{tabular}{|c|c|c|c|c|c|c|c|c|}
\hline \multirow{3}{*}{ Pengetahuan } & \multicolumn{4}{|c|}{ Perilaku Merokok } & \multirow{2}{*}{\multicolumn{2}{|c|}{ Jumlah }} & \multirow{3}{*}{$\underset{\text { Value }}{p}$} & \multirow{2}{*}{ OR } \\
\hline & \multicolumn{2}{|c|}{ Merokok } & \multicolumn{2}{|c|}{ Tidak Merokok } & & & & \\
\hline & $\mathbf{n}$ & $\%$ & $\mathrm{n}$ & $\%$ & $\mathrm{n}$ & $\%$ & & \multirow{4}{*}{14,583} \\
\hline Tinggi & 60 & 78,9 & 9 & 20,5 & 69 & 57,5 & \multirow{3}{*}{0,000} & \\
\hline Rendah & 16 & 21,1 & 35 & 79,5 & 51 & 42,5 & & \\
\hline Jumlah & 76 & 100 & 44 & 100 & 120 & 100 & & \\
\hline \multicolumn{9}{|c|}{$p=0,024$} \\
\hline
\end{tabular}

Berdasarkan tabel hasil analisis hubungan antara pengetahuan dengan perilaku merokok didapatkan 60 (78,9\%) dari 69 responden yang memiliki pengetahuan tinggi adalah merokok. Dari hasil uji statistik chi-square didapatkan $p$ value $=$ 0,000, berarti ada hubungan yang signifikan antara pengetahuan dengan perilaku merokok. 
Tabel 5. Hubungan antara sikap dengan perilaku merokok

\begin{tabular}{|c|c|c|c|c|c|c|c|c|}
\hline \multirow{3}{*}{ Sikap } & \multicolumn{4}{|c|}{ Perilaku Merokok } & \multirow{2}{*}{\multicolumn{2}{|c|}{ Jumlah }} & \multirow{3}{*}{$\underset{\text { Value }}{p}$} & \multirow{2}{*}{$O R$} \\
\hline & \multicolumn{2}{|c|}{ Merokok } & \multicolumn{2}{|c|}{ Tidak Merokok } & & & & \\
\hline & $\mathbf{n}$ & $\%$ & $\mathbf{n}$ & $\%$ & $\mathbf{n}$ & $\%$ & & \multirow{4}{*}{1,829} \\
\hline Positif & 69 & 90,8 & 20 & 45,5 & 89 & 74,2 & \multirow{3}{*}{0,000} & \\
\hline Negatif & 7 & 9,2 & 24 & 54,5 & 31 & 25,8 & & \\
\hline Jumlah & 76 & 100 & 44 & 100 & 120 & 100 & & \\
\hline \multicolumn{9}{|c|}{$p=0,024$} \\
\hline
\end{tabular}

Berdasarkan tabel hasil analisis hubungan antara sikap dengan perilaku merokok didapatkan 69 (90,8\%) dari 89 responden yang memiliki sikap psitif adalah merokok. Dari hasil uji statistik chi-square didapatkan $p$ value $=0,000$, berarti ada hubungan yang signifikan antara sikap dengan perilaku merokok.

\section{Pembahasan}

1. Hubungan antara Pengetahuan dengan Perilaku Merokok

Hasil penelitian menunjukkan ada hubungan yang signifikan antara pengetahuan dengan perilaku merokok. Sejalan dengan penlitian Pakaya (3013) tentang hubungan pengetahuan tentang bahaya merokok dengan perilaku merokok pada siswa SMP Negeri 1 Bulawa yang menunjukkan hasil ada hubungan yang signifikan antara pengetauan tentang bahaya merokok dengan perilaku merokok dengan $\mathrm{p}$ value $=0,03$.

Begitu juga hasil penelitian Purba (2009) tentang hubungan karakteristik, pengetahuan, dan sikap remaja laki laki terhadap kebiasaan merokok di SMU Parulian 1 Medan tahun 2009 menunjukkan bahwa tidak ada hubungan pengetahuan dengan kebiasaan merokok dengan $\mathrm{p}$ value 0,234 .

Pengetahuan adalah segala sesuatu yang diketahui atau kepandaian. Pengetahuan merupakan hasil dari tahu. Ini terjadi setelah seseorang melakukan penginderaan terhadap suatu objek tertentu, yakni indera penglihatan, pendengaran, penciuman, rasa dan raba. Sebagian besar pengetahuan manusia diperoleh melalui mata dan telinga. Pengetahuan / kognitif merupakan domain yang sangat penting dalam membentuk tindakan seseorang (Azwar, 2007).

Pengetahuan adalah keseluruhan fakta kebenaran azas dan ketenangan yang diperoleh manusia. Pengetahuan menunjukkan pada hal-hal yang diketahui (Notoatmodjo, 2007). Pengetahuan adalah merupakan hasil tahu dan ini terjadi setelah orang melakukan pengindraan terhadap suatu objek tertentu (Nursalam, 2001).

Konsep umum yang digunakan untuk mendiagnosis perilaku adalah konsep dari Lawrence Green (1980) (dalam Notoadmodjo, 2007). Menurut Green, salah satu faktor utama yang mempengaruhi perilaku yaitu faktor-faktor predisposisi (predisposing factors). Faktor-faktor ini mencakup pengetahuan dan sikap masyarakat terhadap kesehatan, tradisi, dan kepercayaan masyarakat terhadap hal-hal yang berkaitan dengan kesehatan, system nilai yang dianut masyarakat, tingkat pendidikan, tingkat sosial ekonomi, dan sebagainya.

Menurut pendapat peneliti perilaku yang didasari pengetahuan akan lebih langgeng dari pada perilaku yang tidak didasari oleh pengetahuan. Bila pengetahuan mereka sudah baik tentang merokok maka perilaku merokok akan berkurang. Persamaan hasil penelitian ini dengan penelitian terdahulu yang menunukkan bahwa ada hubungan antara pengetahuan dengan perilaku merokok disebabkan karena sampel yang digunakan adalah remaja dimana pengetahuan remaja masih kurang dan masih dipengaruhi oleh lingkungan atau teman sebaya.

Selain itu, tingginya kebiasaan merokok pada siswa SMA PGRI 2 Palembang disebabkan karena pengaruh dari pergaulan atau teman sebaya. Dimana merokok sudah menjadi tren dalam pergaulan di lingkungan remaja saat ini. Selain itu, hal ini juga dapat disebabkan karena kurangnya pengawasan dari keluarga maupun lingkungan masyarakat.

2. Hubungan antara Sikap dengan Perilaku Merokok

Berdasarkan hasil analisis bivariat didapatkan $\mathrm{p}$ value $=0,000$ ( $\mathrm{p}$ value $<0,05$ ), sehingga ada hubungan yang signifikan antara sikap dengan perilaku merokok.

Berbeda dengan penelitian yang dilakukan Rahmadi (2013) tentang hubungan pengetahuan dan sikap terhadap rokok dengan kebiasaan merokok siswa SMP di kota Padang menujukkan bahwa tidak ada hubungan yang bermakna antara sikap dengan kebiasaan merokok pada siswa SMP dengan $\mathrm{p}$ value 0,155 .

Begitu juga penelitian Purba (2009) tentang hubungan karakteristik, pengetahuan, dan sikap remaja laki - laki terhadap kebiasaan merokok di SMU Parulian 1 Medan tahun 2009 menunjukkan bahwa sikap terhadap perilaku merokok pada remaja dengan $\mathrm{p}$ value $=0,657$.

Berdasarkan teori perilaku yang dikemukakan oleh Green dalam Notoatmodjo (2003) sikap merupakaan faktor predisposisi dalam pembentukan perilaku seseorang. Bila seseorang mempunyai sikap positif terhadap seseuatu 
maka ia akan menerima atau melaksanakan sesuatu itu, dan sebaliknya bila seseorang mempunyai sikap negatif maka ia akan menolak atau tidak melaksanakan sesuatu itu.

Sikap adalah bagaimana pendapat atau penilaian orang atau responden terhadap hal yang terkait dengan kesehatan, sehat-sakit dan faktor yang terkait dengan faktor resiko kesehatan. Newcomb salah seorang ahli psikologi social menyatakan bahwa sikap adalah merupakan kesiapaan atau kesediaan untuk bertindak, dan bukan merupakan pelaksanaan motif tertentu. Dalam kata lain fungsi sikap belum merupakan tindakan (reaksi terbuka) atau aktivitas, akan tetapi merupakan predisposisi perilaku (tindakan), atau reaksi tertutup (Notoatmodjo, 2010).

Berdasarkan literatur dan hasil penelitian, peneliti berpendapat bahwa pemikiran seseorang terhadap suatu objek dipengaruhi oleh faktor emosi individu tersebut, dalam hal ini sikap yang baik tidak akan dapat terlaksana sebagai suatu kepercayaan atau keyakinan yang baik bila individu itu sendiri tidak meyakini sikapnya. Pengaruh emosi serta pengalaman diduga menjadi faktor pemicu seseorang untuk menerima stimulus yang diberikan seperti halnya dengan perilaku merokok.

Hal ini berbeda dengan penelitian sebelumnya disebabkan karena perbedaan rentang umur responden dan keadaan lingkungan sekolah antara peneliti dan penelitit terdahulu. Sehingga hal in mempengaruhi sikap dari responden.

\section{Kesimpulan}

Berdasarkan hasil penelitian yang dilakukan di SMA PGRI 2 Palembang dengan jumlah sampel 82 responden, maka peneliti dapat mengambil kesimpulan sebagai berikut :

1. Ada hubungan yang signifikan antara pengetahuan dengan perilaku merokok $p$ value $=0,000$.

2. Ada hubungan yang signifikan antara sikap dengan perilaku merokok $p$ value $=0,000$

\section{Referensi}

Aula. 2010. Stop Merokok (Sekarang Atau Tidak Sama Sekalai). Jogjakarta:

Azwar, Saifudin. 2007. Sikap Manusia Teori dan Pengukurannya. Pustaka Pelajar, Yogyakarta.

Komalasari D, Helmi AF. 2000. Faktor-faktor Penyebab Perilaku Merokok Pada Remaja. Universitas Gadjah Mada Press (Jurnal).

Mutadin 2012. Tinjauan Banyak Jumlah Perokok. Jakarta: Salemba Medika

Mu'tadin Z, 2002. Remaja dan Rokok. Jakarta : diakses dari http://www.e-psikologi.com/epsi/ individual_detail.asp?id=379 [5 November 2014].

Nurseno. 2009. Sosiologi Pengantar. Solo: PT. Tiga Serangkai Pustaka Mandiri.

Pakaya, 2013. Hubungan Pengetahuan Tentang Bahaya Merokok Dengan Perilaku Merokok Pada Siswa SMP Negeri Bulawa (Skrispi).

Purba. 2009. Hubungan Karakteristik, Pengetahuan, dan Sikap Remaja Laki - Laki Terhadap kebiasaan Merokok di SMU Parulian Medan Tahun 2009 (Skripsi).

Rahmadi, 2013. Hubungan Pengetahuan dan Sikap Terhadap Rokok dengan Kebiasaan Merokok Siswa SMP di Kota Padang (Jurnal).

Rozy. B, 2010. Faktor-Faktor Yang Mempengaruhi Kenakalan Pada Lingkungan Siswa. Universitas Mulawarman, Samarinda (Skripsi). 